\title{
Synthesis of new enantiopure dimethyl-substituted pyridino-18- crown-6 ether type macrocycles containing different substituents at position 4 of the pyridine ring for enantiomeric recognition studies
}

\author{
Tünde Tóth, ${ }^{a}$ Péter Huszthy, ${ }^{a} b^{*}$ József Kupai, ${ }^{b}$ and József Nyitrai ${ }^{b}$ \\ ${ }^{a}$ Research Group for Alkaloid Chemistry of the Hungarian Academy of Sciences H-1521 \\ Budapest, Hungary \\ ${ }^{b}$ Department of Organic Chemistry and Technology, Budapest University of Technology and \\ Economics H-1521 Budapest, Hungary
}

E-mail: huszthy@mail.bme.hu

\section{Dedicated to Professor Csaba Szántay on the occasion of his $80^{\text {th }}$ birthday}

\begin{abstract}
New enantiomerically pure dimethyl-substituted pyridino-18-crown-6 ether derivatives containing chloro, $\mathrm{N}$-allylamino, $\mathrm{N}$-allylacetamido, $\mathrm{N}$-benzylamino and cyano functional groups at position 4 of the pyridine ring have been synthetized. This paper also reports the transformation of the known enantiopure parent dimethyl-substituted pyridino-18-crown-6 ether to its new $\mathrm{N}$-oxide derivative and the $\mathrm{O}$-methylation of the latter. These ligands are good candidates for enantiomeric recognition studies of protonated primary amines, amino acids and their derivatives.
\end{abstract}

Keywords: Chiral crown ethers, pyridono-18-crown-6 ligands, macrocycles, heterocycles, enantiomeric recognition, chiral stationary phases

\section{Introduction}

Enantiomeric recognition which is a ubiquitous and vital phenomenon in Nature can also be brought about using relatively simple chiral synthetic host molecules such as crown ethers. Studies using these chiral synthetic mimics not only help to understand better enantiomeric recognition in the living organisms, but it can also lead to the development of new enantioselective sensor and selector molecules with wide applications. ${ }^{1}$ The first synthetic chiral crown ethers containing the twisted 1,1'-binaphthyl unit were prepared by Cram and coworkers in the 1970's ${ }^{2}$ and these optically pure host molecules showed remarkable enantiomeric recognition towards protonated chiral amines and amino acid esters. ${ }^{3}$ Since the seminal work of 
Cram and coworkers a large number of different chiral crown ethers have been synthetized and studied for enantiomeric recognition towards protonated chiral primary amines, amino acids and their derivates. ${ }^{1,4-7}$

The study of enantioselective recognition of protonated chiral primary amines, amino acids and their derivatives is of great significance since these compounds are basic building blocks of important biomolecules. ${ }^{5}$

Chiral pyridino-18-crown-6 ether type macrocycles have received considerable attention in the past quarter of century due to their great ability of chiral discrimination towards the above mentioned amino compounds. ${ }^{8-26}$

Selected enantiopure pyridino-18-crown-6 ethers have been attached by covalent bonds to solid supports such as silica gel $^{27-32}$ and Merrifield polymer resin ${ }^{33}$ and the chiral stationary phases (CSPs) so obtained have been used for chromatographic enantioseparation of racemic protonated primary amines, amino acids and their derivates.

Among chiral pyridino-18-crown-6 ethers the dimethyl-substituted one $[(S, S)$-1, Figure 1$)$ has been studied the most ${ }^{8,9,12,14-16,18,20,23}$, because its enantiopure precursor viz. $(2 S, 12 S)-4,7,10$ trioxatridecane-2,12-diol can easily be prepared in a large quantity starting from commercially available and relatively cheap starting materials. ${ }^{33-35}$

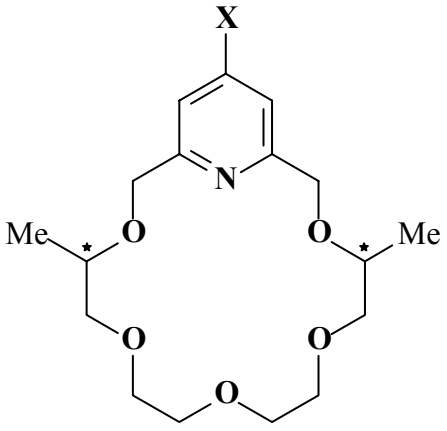

$(S, S)-\mathbf{1}: \mathrm{X}=\mathrm{H}$
$(S, S)-\mathbf{2}: \mathrm{X}=\mathrm{OCH}_{2} \mathrm{CH}=\mathrm{CH}_{2}$
$(S, S)-\mathbf{3}: \mathrm{X}=\mathrm{O}\left(\mathrm{CH}_{2}\right)_{3} \mathrm{OCPh}_{3}$
$(S, S)-\mathbf{4}: \mathrm{X}=\mathrm{OBn}$
$(S, S)-\mathbf{5}: \mathrm{X}=\mathrm{OTHP}$
$(S, S)-\mathbf{6}: \mathrm{X}=\mathrm{O}\left(\mathrm{CH}_{2}\right)_{3} \mathrm{OH}$
$(S, S)-\mathbf{7}: \mathrm{X}=\mathrm{OCH}_{2} \mathrm{CO}_{2} \mathrm{Bn}$
$(S, S)-\mathbf{8}: \mathrm{X}=\mathrm{OCH}_{2} \mathrm{CO}_{2} \mathrm{H}$
$(S, S)-\mathbf{9}: \mathrm{X}=\mathrm{OCH}_{2} \mathrm{CONHCH}_{2}-\mathrm{CH}=\mathrm{CH}_{2}$

Note: $\mathrm{Bn}=$ benzyl, THP $=$ tetrahydropyranyl

Figure 1. Schematics of the reported enantiopure dimethyl-substituted pyridino-18-crown-6 ether parent compound $(S, S)-\mathbf{1}$ and its derivatives $(S, S)-\mathbf{2}-(S, S)-\mathbf{9}$. 
Besides the parent crown ether $(S, S)-\mathbf{1}^{14}$, its derivatives $(S, S)-\mathbf{2}^{27},(S, S)-\mathbf{3}-(S, S)-\mathbf{6}^{33},(S, S)-\mathbf{7}$, $(S, S)-\mathbf{8}^{31}$ and $(S, S)-\mathbf{9}^{32}$ (Figure 1) have also been synthetized and used as precursors for the preparation of the above mentioned CSPs.

Because of their relatively easy synthesis, in all the cases of these optically active dimethylsubstituted pyridino-18-crown-6 ether derivatives, the funtional groups have been attached to the pyridine ring exclusively through an oxygen atom. The manipulation and application of these $O$ derivatized pyridino ligands, however, are restricted, because nucleophilic attack can take place at position 4 of the pyridine ring as we observed it in the case of the reaction of $(S, S)-6$ with an alkoxide. $^{33}$

Very recently we reported the preparation of pyridino-crown ether derivative $(S, S)$-9 (Figure 1) which is a very useful precursor of an efficient CSP. ${ }^{32} \mathrm{We}$ obtained this precursor from enantiopure dimethyl-substituted pyridono-18-crown-6 ligand $(S, S)$-10 and $N$-allylchloroacetamide (11) using $\mathrm{K}_{2} \mathrm{CO}_{3}$ as a base in DMF (Scheme 1).

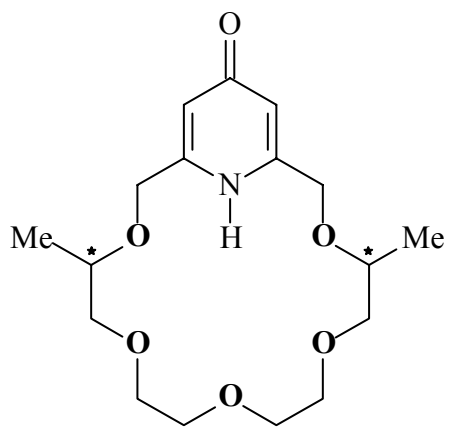

$(S, S)-\mathbf{1 0}$

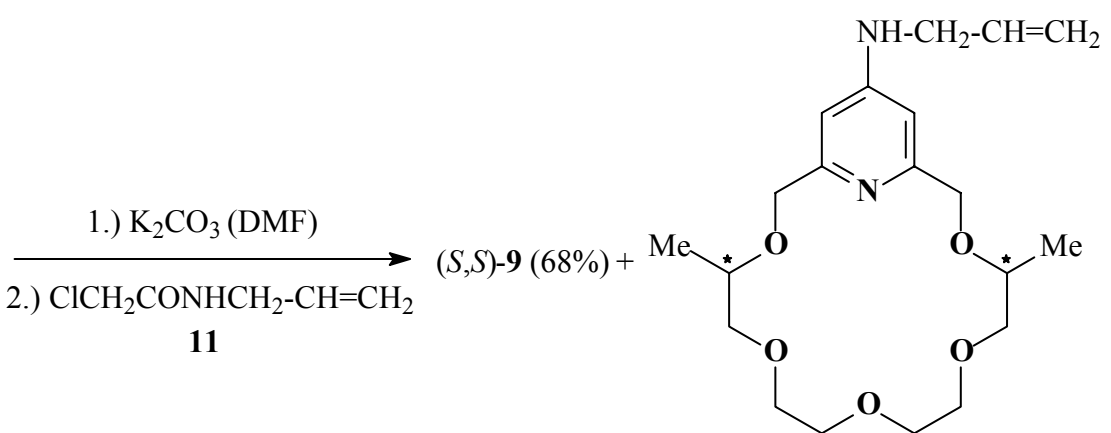

$(S, S)-12(22 \%)$

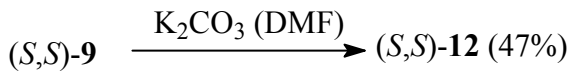

Scheme 1. Preparation of $N$-allylcarbamoyl-methyleneoxy-pyridino-18-crown-6 ligand (S,S)-9 with formation of side product $N$-allylaminopyridino-18-crown-6 ether $(S, S)$-12 and also the degradation of $(S, S)-\mathbf{9}$ to $(S, S)-\mathbf{1 2}$.

This year we started to prepare larger quantities of ligand $(S, S)-9$, and when we changed the reaction conditions to improve the yield of this important precursor, we noticed that by increasing the reaction time, and especially the reaction temperature, an appreciable amount of a new product formed which, after isolation and thorough structural analysis, proved to be the unreported $N$-allylaminopyridino-18-crown-6 ether $(S, S)$-12. The latter was easily transformed to its $N$-acetyl derivative $(S, S)$-13 (see later) which can be a promising precursor for the preparation of a new CSP using the reported procedure. ${ }^{32}$

The formation of $N$-allylaminopyridino-18-crown-6 ligand $(S, S)$-12 promt and motivated us to start the preparation of new enantiopure dimethyl-substituted pyridino-18-crown- 6 ether 
derivatives containing other atoms than oxygen at position 4 of the pyridine ring for the purpose of developing enantioselective sensor and selector molecules with wide applicatioins.

This paper reports only the preparation and characterization of the new derivatives. Their applications as enantioselective sensor and selector molecules will be published in an other paper when the work connected to them is finished.

\section{Results and Discussion}

As we mentioned above, when we carried out the reaction of pyridino-crown ether $(S, S)-\mathbf{1 0}$ with chloroacetamide 11 in the presence of $\mathrm{K}_{2} \mathrm{CO}_{3}$ in DMF (Scheme 1.) for prolonged time and especially at elevated temperature, besides the $N$-allylcarbamoyl-methyleneoxy-pyridino-crown ether $(S, S)-9$, appreciable amount of $N$-allylaminopyridino-crown ether $(S, S)$-12 was also formed. We also treated $N$-allylcarbamoyl-methyleneoxy-pyridino-crown ether $(S, S)-9$ with $\mathrm{K}_{2} \mathrm{CO}_{3}$ in DMF in the absence of $(S, S)-\mathbf{1 0}$ and 11, otherwise in the same reaction conditions. The TLC analysis showed that at elevated temperature the degradation of $(S, S)$-9 to $(S, S)-\mathbf{1 2}$ was much faster, but completing the reaction took a long time even at elevated temperature and consequently the yield for $(S, S)-\mathbf{1 2}$ was not very good (Scheme 1).

With the help of Scheme 2. we can rationalize the formation of $(S, S)$-12 from $(S, S)-9$. We would like to emphasize in advance that the deprotonation of $(S, S)-9$ in the given circumstances is not favourable and the equilibrium is shifted backwards to a great extent, but because the last step is irrevesible (formation of gaseous products), the mechanism outlined in Scheme 2 is feasible.

Thus, we suppose that after deprotonation the amide nitrogen attacks the carbon at position 4 of the pyridine ring to give intermediate $(S, S)$-14I. The latter takes up a proton (either from amide $(S, S)-9$ or from the hydrogencarbonate anion which forms in the first step, see above) and the intermediate $(S, S)$-15I so formed breaks down to give formaldehyde, carbon monoxide and $(S, S)$-12. We note here that adding allylamine to the reaction mixture did not raise the yield of $(S, S)$-12 which excludes the attack at position 4 of the pyridine ring of $(S, S)-9$ by allylamine in case of forming some way. 


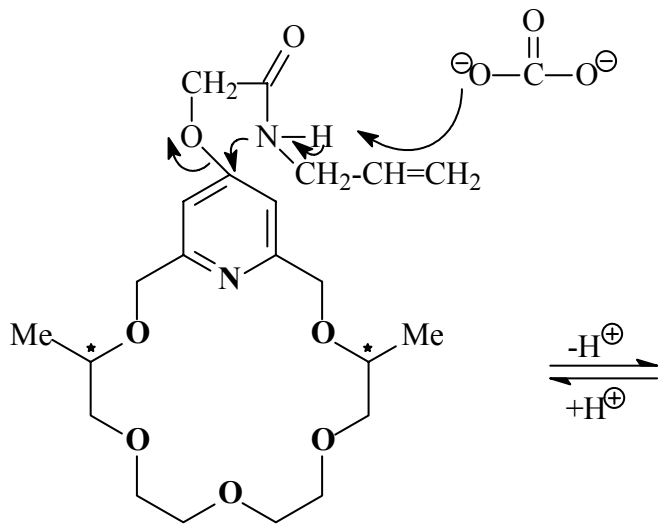

$(S, S)-9$

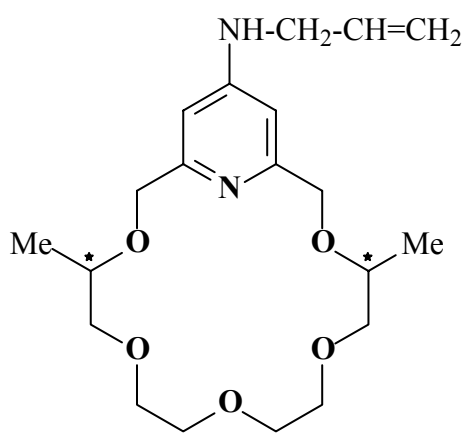

$(S, S)-12$<smiles></smiles>

$(S, S)-14 I$

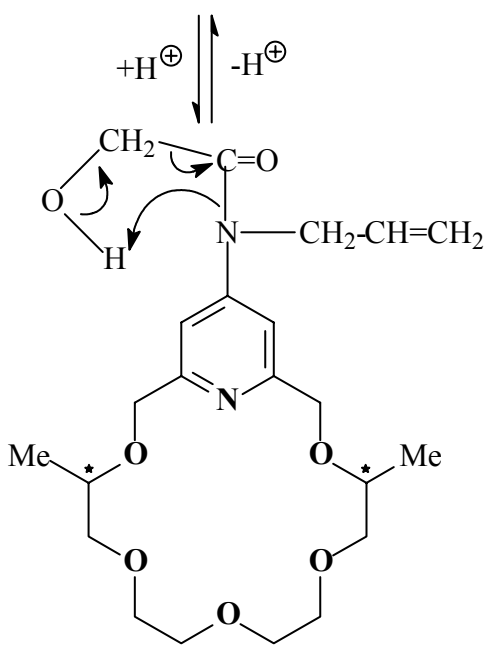

$(S, S)-\mathbf{1 5 I}$

Scheme 2. A proposed mechanism for the formation of $N$-allylaminopyridino-18-crown-6 ligand $(S, S)$-12 from $N$-allylcarbamoyl-methyleneoxy-pyridino-18-crown-6 ether $(S, S)$-9.

As we were confirmed that $(S, S)-\mathbf{1 2}$ is a very useful starting material for new CSPs, we wanted to prepare it by another procedure giving a better yield. Lüning and coworkers reported that 4-chloro-2,6-pyridinedimethanol could be transformed to 4-diethylamino-2,6pyridinedimethanol in a good yield by heating the former with an excess of diethylamine at elevated temperature in an autoclave. ${ }^{36}$ Applying Lüning's method for the preparation of $(S, S)-\mathbf{1 2}$ first we needed the unreported enantiopure dimethyl-substituted chloropyridino-18-crown-6 ether $(S, S)$-16 (Scheme 3) which we obtained by treating the known pyridono-crown ether $(S, S)$ $\mathbf{1 0}^{33}$ with an excess of thionyl chloride in boiling chloroform in the presence of catalytic amount of DMF. Heating chloropyridino-crown ether $(S, S)$-16 with an excess of allylamine in a sealed tube rendered ligand $(S, S)-\mathbf{1 2}$ in a good yield. The latter was transformed to its $N$-acetyl derivative $(S, S)$-13 in a very mild reaction conditions with almost quantitative yield (Scheme 3 ). 


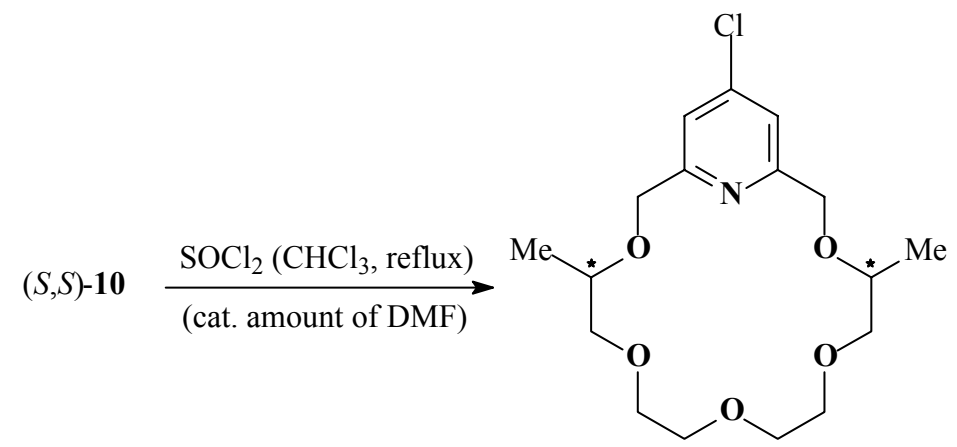

$(S, S)-\mathbf{1 6}(69 \%)$
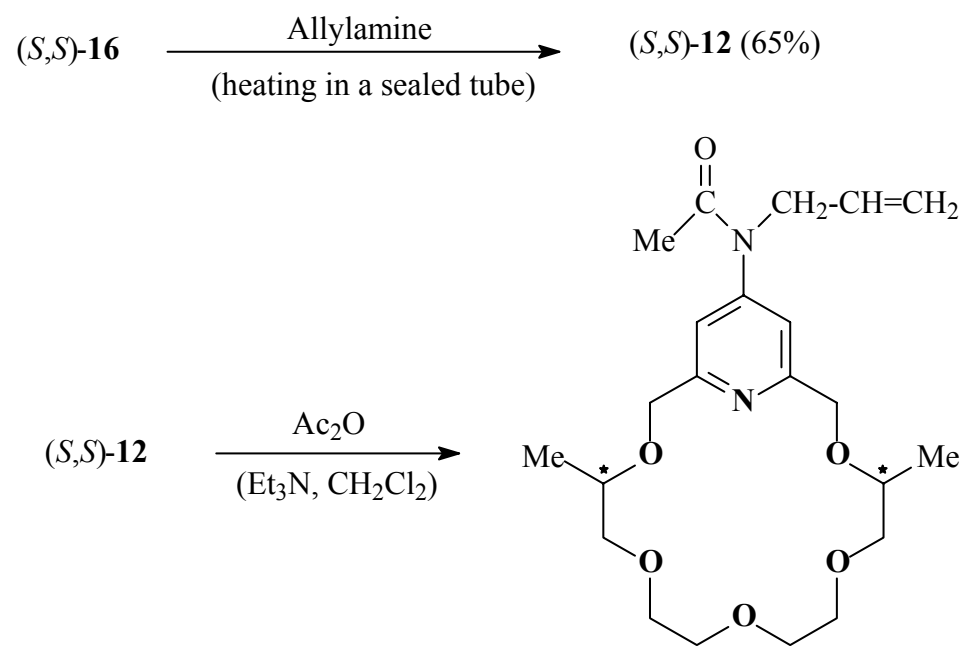

$(S, S)-\mathbf{1 3}(98 \%)$

Scheme 3. Preparation of enantiopure chloropyridino-18-crown-6 ether $(S, S)$-16, its transformation to $N$-allylaminopyridino-crown ether $(S, S)$-12 and acetylation of the latter.

Encouraged by the succesful transformation of chloropyridino-crown ether $(S, S)$-16 to Nallylaminopyridino ligand $(S, S)-\mathbf{1 2}$, we also tried the reaction of $(S, S)$-16 with an excess of benzylamine at elevated temperature. This reaction also went well giving the unreported Nbenzylaminopyridino ligand $(S, S)-17$ in an acceptable yield (Scheme 4).

Enantiopure N-benzylaminopyridino ligand $(S, S)$-17 also seems to be a very useful precursor for different pyridino-crown ether derivatives. By removal of the benzyl group from $(S, S)-\mathbf{1 7}$ by catalytic hydrogenation we can open new routes for further synthetic transformations.

We have long wanted to prepare enantiopure dimethyl-substituted cyanopyridino-18-crown-6 ether $(S, S)$-18 (Scheme 5), because its cyano group can be transformed to both formyl and carboxyl groups which are excellent functional groups for obtaining new pyridino-crown etherbased sensor and selector molecules. 


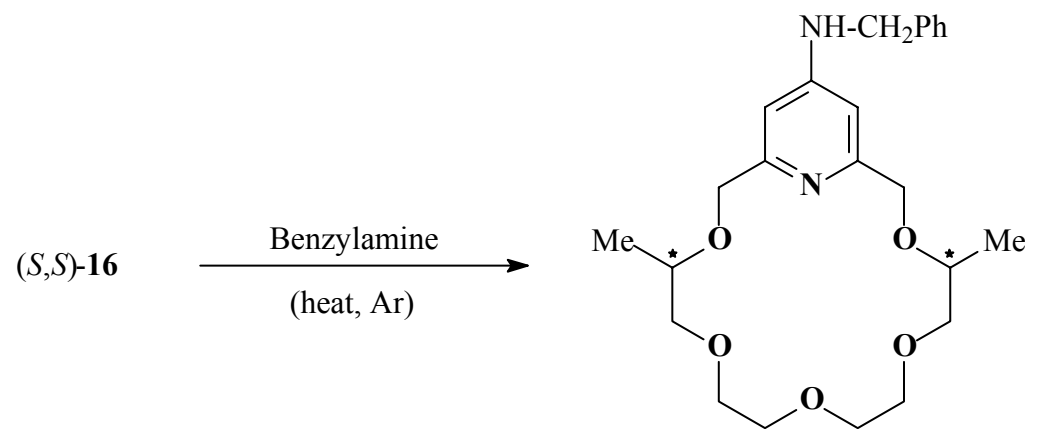

$(S, S)-17(62 \%)$

Scheme 4. Preparation of $N$-benzylaminopyridino-18-crown-6 ether $(S, S)$-17 from chloropyridino-18-crown ether $(S, S)-\mathbf{1 6}$.

Studying the reports connected with our plan in the literature we found that Feely and Beavers described the preparation of 4-cyano-2,6-dimethylpyridine starting from 2,6dimethylpyridine by the following steps. ${ }^{37}$

2,6-Dimethylpyridine was treated with $30 \%$ aqueous hydrogen peroxide in glacial acetic acid to obtain the relevant $N$-oxide which was converted to $N$-methoxy-2,6-dimethylpyridinium methyl sulfate. In the last step the $N$-methoxypyridinium salt was reacted with an excess of potassium cyanide in water to give 4-cyano-2,6-dimethylpyridine.

For the preparation of cyanopyridino-crown ether $(S, S)$-18 (Scheme 5) we started from the reported enantiopure dimethyl-substituted parent pyridino-crown ether $(S, S)$-1 (see also Figure 1.). ${ }^{14}$ When we treated pyridino-crown ether $(S, S)$-1 with hydrogen peroxide in acetic acid in the same way as reported for 2,6-dimethylpyridine ${ }^{37}$ we obtained only a few percent of N-oxide $(S, S)$-19, but using $m$-chloroperbenzoic acid (MCPBA) in $\mathrm{CH}_{2} \mathrm{Cl}_{2}$ (Figure 5) we got a good yield for $(S, S)$-19. Pyridino-crown ether $N$-oxide $(S, S)$-19 was reacted with dimethyl sulfate without any solvent to give $N$-methoxypyridinium salt $(S, S)$-20 in a good yield. The latter was then transformed to cyanopyridino-crown ether $(S, S)$-18 using sodium cyanide in a methanol-water mixture with a rather low yield. 


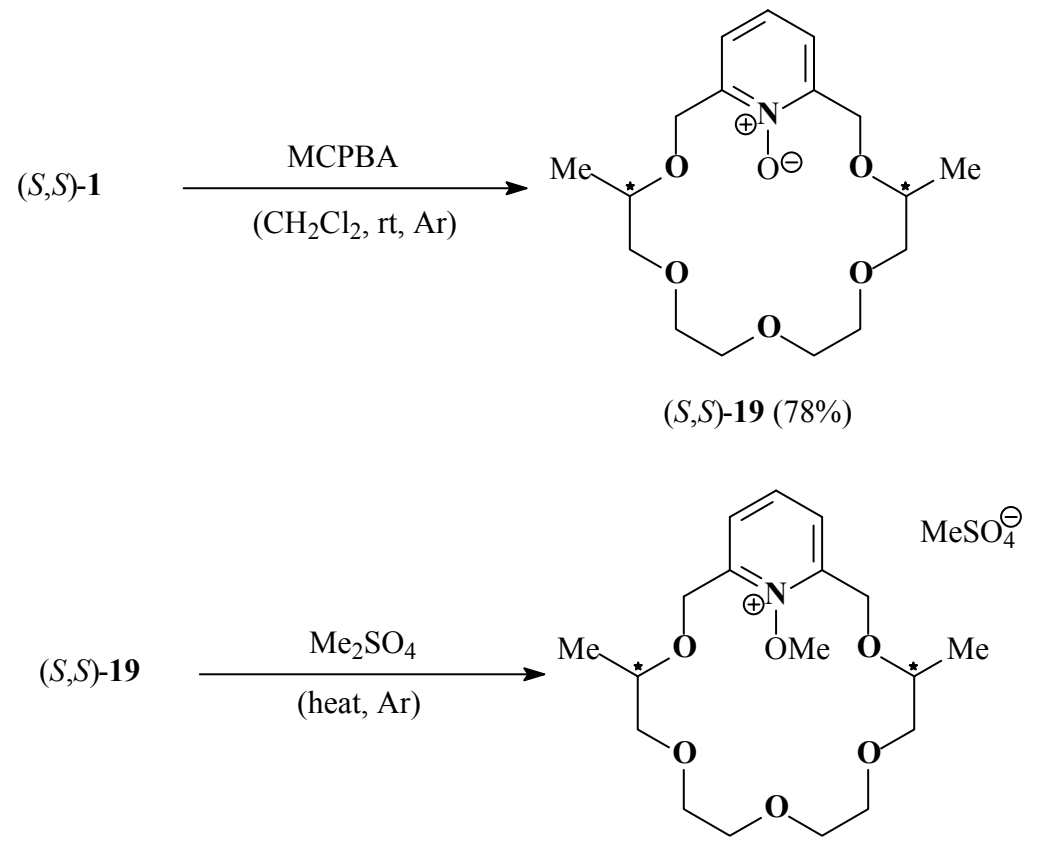

$(S, S)-\mathbf{2 0}(75 \%)$

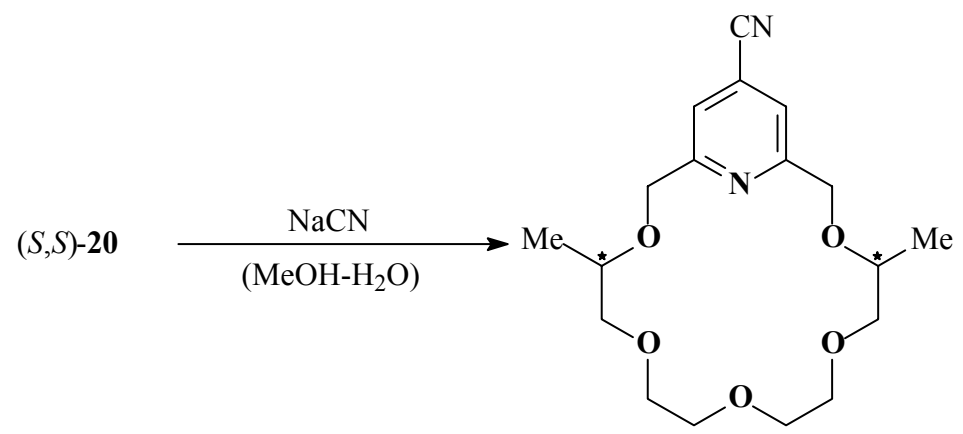

$(S, S)-18(13 \%)$

Scheme 5. Preparation of cyanopyridino-18-crown-6 ether $(S, S)$-18 from parent pyridino ligand $(S, S)-1$.

\section{Conclusions}

We can conclude that the reported enantiomerically pure dimethyl-substituted pyridino- and pyridono-18-crown-6 ethers $[(S, S)-1$ and $(S, S)$-10, respectively) can be transformed easily to new enantiopure derivatives such as $(S, S)$-12, $(S, S) \mathbf{- 1 3},(S, S)-\mathbf{1 6},(S, S)-\mathbf{1 7},(S, S)-\mathbf{1 8},(S, S)$-19 and $(S, S)$ 20 which are from one hand good candidates for enantiomeric recognition studies and from the other hand are very useful precursors for enantioselective sensor and selector molecules with wide applications. 


\section{Experimental Section}

General Procedures. Infrared spectra were recorded on a Zeiss Specord IR 75 spectrometer. Optical rotations were taken on a Perkin-Elmer 241 polarimeter that was calibrated by measuring the optical rotations of both enantiomers of menthol. ${ }^{1} \mathrm{H}(500 \mathrm{MHz})$ and ${ }^{13} \mathrm{C}(125 \mathrm{MHz}) \mathrm{NMR}$ spectra were obtained on a Bruker DRX-500 Avance spectrometer. Mass spectra were recorded on a ZQ 2000 MS instrument (Waters Corp.) using ESI method. Elemental analyses were performed in the Microanalytical Laboratory of the Department of Organic Chemistry, Institute for Chemistry, L. Eötvös University, Budapest, Hungary. Melting points were taken on a Boetius micro-melting point apparatus and were uncorrected. Starting materials were purchased from Aldrich Chemical Company unless otherwise noted. Silica gel $60 \mathrm{~F}_{254}$ (Merck) and aluminium oxide $60 \mathrm{~F}_{254}$ neutral type $\mathrm{E}$ (Merck) plates were used for TLC. Aluminium oxide (neutral, activated, Brockman I) and silica gel 60 (70-230 mesh, Merck) were used for column chromatography. Ratios of solvents for the eluents are given in volumes $(\mathrm{mL} / \mathrm{mL})$. Solvents were dried and purified according to well established ${ }^{38}$ methods. Evaporations were carried out under reduced pressure unless otherwise stated.

\section{$(4 S, 14 S)-N$-Allyl-4,14-dimethyl-3,6,9,12,15-pentaoxa-21-azabicyclo[15.3.1]heneicosa- $1(21), 17,19-$ trien-19-amine $[(S, S)-12]$}

A. From the the reaction of $(S, S)-10$ and 11. To a solution of dimethyl-substituted pyridono18-crown-6 ether $(S, S)$-10 semihydrate $(1.0 \mathrm{~g}, 2.9 \mathrm{mmol})$ in pure and dry DMF $(30 \mathrm{~mL})$ was added first finely powdered anhydrous $\mathrm{K}_{2} \mathrm{CO}_{3}(1.2 \mathrm{~g}, 8.7 \mathrm{mmol})$ followed by $N$-allylchloroacetamide (11) $(1.11 \mathrm{~g}, 8.3 \mathrm{mmol})$, and the resulting mixture was stirred at $\mathrm{rt}$ under Ar for 3 days and at $70^{\circ} \mathrm{C}$ for 8 days. Monitoring the progress of the reaction by TLC it showed an increasing spot at $R_{\mathrm{f}}=0.2\left(\mathrm{Al}_{2} \mathrm{O}_{3}\right.$, using toluene: $\mathrm{EtOH} \mathrm{10:1} \mathrm{mixture} \mathrm{as} \mathrm{an} \mathrm{eluent)} \mathrm{for}(S, S)-\mathbf{1 2}$. After the above indicated time the solvent was removed and the residue was dissolved in a mixture of $\mathrm{CH}_{2} \mathrm{Cl}_{2}(50 \mathrm{~mL})$ and water $(50 \mathrm{~mL})$. The phases were shaken well and separated. The aqueous phase was shaken with $\mathrm{CH}_{2} \mathrm{Cl}_{2}(3 \mathrm{X} 30 \mathrm{~mL})$. The combined organic phase was dried over $\mathrm{MgSO}_{4}$, filtered and the solvent was removed. The residue was subjected to column chromatography on $\mathrm{Al}_{2} \mathrm{O}_{3}$ using toluene:EtOH 40:1 mixture as an eluent to give besides the reported ligand $(S, S)-9$ [32] $(0.86 \mathrm{~g}, 68 \%)$ the new $N$-allylaminopyridino-crown ether $(S, S)$-12 $\left(0.26 \mathrm{~g}, 22 \%\right.$, thick oil) as a monohydrate. $[\alpha]^{25}=+10.24\left(c 0.835, \mathrm{CH}_{2} \mathrm{Cl}_{2}\right)$; IR (neat) $v_{\max }$ $3520,3336,3120,3088,3040,2872,1644,1632,1612,1524,1468,1352,1288,1116,984,920$, $844,616 \mathrm{~cm}^{-1} ;{ }^{1} \mathrm{H} \mathrm{NMR}\left(\mathrm{CDCl}_{3}\right) \delta 1.15(\mathrm{~d}, J=6.5 \mathrm{~Hz}, 6 \mathrm{H}), 2.53\left(\right.$ broad s, complexed $\left.\mathrm{H}_{2} \mathrm{O}, 2 \mathrm{H}\right)$, 3.41-3.42 (m, 2H), 3.44-3.62 (m, 10H), 3.79-3.82 (m, 4H), 4.38 (broad s, NH, 1H), the diastereotopic benzyl-type protons gave an $\mathrm{AB}$ quartet $\delta_{\mathrm{A}}: 4.60$ and $\delta_{\mathrm{B}}: 4.66(J=13 \mathrm{~Hz}, 4 \mathrm{H})$, 5.16-5.27 (m, 2H), 5.84-5.96 (m, $1 \mathrm{H}), 6.47(\mathrm{~s}, 2 \mathrm{H}) ;{ }^{13} \mathrm{C} \mathrm{NMR}\left(\mathrm{CDCl}_{3}\right) \delta$ 17.32, 45.36, 70.73, 70.85, 72.03, 73.60, 75.86, 104.86, 116.90, 134.18, 154.67, 158.52. MS: $381(\mathrm{M}+1)^{+}$; Anal. Calcd. for $\mathrm{C}_{20} \mathrm{H}_{32} \mathrm{~N}_{2} \mathrm{O}_{5} \bullet \mathrm{H}_{2} \mathrm{O}: \mathrm{C}, 60.28 ; \mathrm{H}, 8.60 ; \mathrm{N}, 7.03$. Found C, 60.06; H, 8.52; N, 6.96. 
B. From the degradation of $(S, S)-9$. To a solution of $N$-allylcarbamoyl-methyleneoxy-pyridinocrown ether $(S, S)-9(636 \mathrm{mg}, 1.45 \mathrm{mmol})$ in pure and dry DMF $(15 \mathrm{~mL})$ was added finely powdered anhydrous $\mathrm{K}_{2} \mathrm{CO}_{3}(0.6 \mathrm{~g}, 4.3 \mathrm{mmol})$ and the resulting mixture was stirred at $\mathrm{rt}$ under Ar for 3 days and at $70^{\circ} \mathrm{C}$ for 15 days. After the reaction was completed the mixture was worked up, and the crude product was purified as above (A.)) to give $(S, S)$-12 (270 mg, 47\%) which was identical in every respect to that obtained by the reaction described above under $\mathbf{A}$.).

C. From $(S, S)-16$ and allylamine. Chloropyridino-crown ether $(S, S)-16(200 \mathrm{mg} ; 0,56 \mathrm{mmol})$ and allylamine $(8 \mathrm{~mL}, 6.09 \mathrm{~g}, 107 \mathrm{mmol})$ were heated in a sealed tube at $120^{\circ} \mathrm{C}$ for a week. The excess of allylamine was removed uder reduced pressure, the residue was taken up in $\mathrm{CH}_{2} \mathrm{Cl}_{2}$ (30 $\mathrm{mL}$ ) and the solution was washed with $12.5 \%$ aqueous tetramethylammonium hydroxide $(4 \mathrm{~mL})$. The aqueous layer was extracted with $\mathrm{CH}_{2} \mathrm{Cl}_{2}(3 \mathrm{X} 10 \mathrm{~mL})$. The combined organic phase was dried over $\mathrm{MgSO}_{4}$, filtered and the solvent evaporated. The crude product was purified as above to give $(S, S)-12(144 \mathrm{mg}, 65 \%)$ which was identical in every respect to that obtained by the reactions described above under $\mathbf{A}$ and $\mathbf{B}$.

$N$-Allyl- $N$-[(4S,14S)-4,14-dimethyl-3,6,9,12,15-pentaoxa-21-azabicyclo[15.3.1]heneicosa1(21),17,19-trien-19-yl]acetamide $[(S, S)$-13]. To a solution of $N$-allylaminopyridino-crown ether $(S, S)-12(88 \mathrm{mg}, 0.22 \mathrm{mmol})$ in pure and dry $\mathrm{CH}_{2} \mathrm{Cl}_{2}(0.5 \mathrm{~mL})$ was added first triethylamine $(0.4 \mathrm{~mL}, 290 \mathrm{mg}, 2.87 \mathrm{mmol})$ followed by acetic anhydride $(0.2 \mathrm{~mL}, 216 \mathrm{mg}, 2.12$ $\mathrm{mmol}$ ), and the resulting mixture was stirred at $\mathrm{rt}$ under Ar for 6 days. The volatile components were removed and the residue was dissolved in a mixture of $\mathrm{CH}_{2} \mathrm{Cl}_{2}(5 \mathrm{~mL})$ and $12.5 \%$ aqueous tetramethylammonium hydroxide $(3 \mathrm{~mL})$. The aqueous layer was extracted with $\mathrm{CH}_{2} \mathrm{Cl}_{2}(3 \mathrm{X} 2$ $\mathrm{mL}$ ). The combined organic phase was dried over $\mathrm{MgSO}_{4}$, filtered and the solvent evaporated to give pure $N$-acetyl derivative $(S, S)-\mathbf{1 3}\left(95 \mathrm{mg}, 98 \%\right.$, thick oil) as a monohydrate. $[\alpha]^{25}{ }_{\mathrm{D}}=+6.47$ (c 1.50, $\mathrm{CH}_{2} \mathrm{Cl}_{2}$ ); IR (neat) $v_{\max } 3320,3088,2872,1672,1620,1596,1452,1380,1264,1116$, 924, 880, $804 \mathrm{~cm}^{-1} ;{ }^{1} \mathrm{H}$ NMR $\left(\mathrm{CDCl}_{3}\right) \delta 1.17(\mathrm{~d}, J=6 \mathrm{~Hz}, 6 \mathrm{H}), 2.01(\mathrm{~s}, 3 \mathrm{H}), 2.23$ (broad s, complexed $\left.\mathrm{H}_{2} \mathrm{O}, 2 \mathrm{H}\right), 3.46-3.66(\mathrm{~m}, 12 \mathrm{H}), 3.81-3.84(\mathrm{~m}, 2 \mathrm{H}), 4.27-4.39(\mathrm{~m}, 2 \mathrm{H}), 4.84(\mathrm{~s}, 4 \mathrm{H})$, 5.12-5.18 (m, 2H), 5.84-5.90 (m, $1 \mathrm{H}), 7.09(\mathrm{~s}, 2 \mathrm{H}) ;{ }^{13} \mathrm{C} \mathrm{NMR}\left(\mathrm{CDCl}_{3}\right) \delta 17.27,23.05,51.99$, 70.84, 71.02, 71.72, 74.20, 76.38, 118.05, 118.31, 133.07, 151.53, 160.93, 169.74; MS: 423 $(\mathrm{M}+1)^{+}$; Anal. Calcd. for $\mathrm{C}_{22} \mathrm{H}_{34} \mathrm{~N}_{2} \mathrm{O}_{6} \cdot \mathrm{H}_{2} \mathrm{O}: \mathrm{C}, 59.98 ; \mathrm{H}, 8.24 ; \mathrm{N}, 6.36$. Found C, 59.86; H, 8.32; $\mathrm{N}, 6.29$.

$(4 S, 14 S)$-19-Chloro-4,14-dimethyl-3,6,9,12,15-pentaoxa-21-azabicyclo[15.3.1] heneicosa-

1(21),17,19-trien $[(S, S)$-16].To a solution of pyridono-crown ether $(S, S)$-10 semihydrate $(620$ $\mathrm{mg}, 1.77 \mathrm{mmol}$ ) in pure and dry $\mathrm{CHCl}_{3}(16 \mathrm{~mL}$ ) was added first pure and dry DMF (two drops) followed by thionyl chloride $(3.2 \mathrm{~mL}, 5.22 \mathrm{~g}, 43.9 \mathrm{mmol})$, and the resulting mixture was stirred at reflux temperature under Ar for $2 \mathrm{~h}$. The volatile components were removed and the residue was dissolved in a mixture of $\mathrm{CH}_{2} \mathrm{Cl}_{2}(80 \mathrm{~mL})$ and $12.5 \%$ aqueous tetramethylammonium hydroxide $(30 \mathrm{~mL})$. The aqueous layer was extracted with $\mathrm{CH}_{2} \mathrm{Cl}_{2}(3 \mathrm{X} 20 \mathrm{~mL})$. The combined organic phase was dried over $\mathrm{MgSO}_{4}$, filtered and the solvent evaporated. The crude product was purified by column chromatography on $\mathrm{Al}_{2} \mathrm{O}_{3}$ using toluene: $\mathrm{EtOH} 120: 1$. as an eluent to give $(S, S)-16(439 \mathrm{mg}, 69 \%)$ as an oil. $[\alpha]^{25}=+17.5\left(c \quad 0.814, \mathrm{CH}_{2} \mathrm{Cl}_{2}\right)$; IR (neat) $v_{\max } 3064,2864$, 
1576, 1456, 1416, 1336, 1280, 1120, $856 \mathrm{~cm}^{-1} ;{ }^{1} \mathrm{H}$ NMR $\left(500 \mathrm{MHz}, \mathrm{CDCl}_{3}\right) \delta 1.17$ (d, $J=6.5$ $\mathrm{Hz}, 6 \mathrm{H}), 3.45-3.64(\mathrm{~m}, 12 \mathrm{H}), 3.79-3.85(\mathrm{~m}, 2 \mathrm{H}), 4.81(\mathrm{~s}, 4 \mathrm{H}), 7.27(\mathrm{~s}, 2 \mathrm{H}) ;{ }^{13} \mathrm{C} \mathrm{NMR}\left(\mathrm{CDCl}_{3}\right) \delta$ 17.02, 70.66, 70.88, 71.35, 74.01, 76.19, 120,35, 144.74, 160.33; MS: $360(\mathrm{M}+1)^{+}$. Anal. Calcd. for $\mathrm{C}_{17} \mathrm{H}_{26} \mathrm{ClNO}_{5}$ : C, 56.74; H, 7.28; N, 3.89. Found C, 56.70; H, 7.07; N, 3.84 .

(4S,14S)- $N$-Benzyl-4,14-dimethyl-3,6,9,12,15-pentaoxa-21-azabicyclo[15.3.1] heneicosa1(21),17,19-trien-19-amine [ $(S, S)$-17]. A solution of chloropyridono-crown ether $(S, S)$-16 (400 $\mathrm{mg}, 1.11 \mathrm{mmol})$ in pure and dry benzylamine $(16 \mathrm{~mL}, 15.70 \mathrm{~g}, 146 \mathrm{mmol})$ was stirred at $140^{\circ} \mathrm{C}$ under Ar for 2 days. The excess of benzylamine was removed (in the end at $0.05 \mathrm{mmHg}$ ) and the crude product was purified in the same way as described above for $\mathrm{N}$-allylaminopyridino-crown ether $(S, S)-12$ (under C.) ) to give $(S, S)-17\left(310 \mathrm{mg}, 62 \%\right.$, thick oil) as a monohydrate. $[\alpha]^{25}=$ $+9.43\left(c\right.$ 0.101, $\mathrm{CH}_{2} \mathrm{Cl}_{2}$ ); IR (neat) $v_{\max } 3530,3344,3256,3170,3120,3088,3032,3016,2872$, $1612,1524,1504,1496,1456,1352,1264,1112,984,844,736,696 \mathrm{~cm}^{-1} ;{ }^{1} \mathrm{H} \mathrm{NMR}\left(\mathrm{CDCl}_{3}\right) \delta$ $1.05(\mathrm{~d}, J=6 \mathrm{~Hz}, 6 \mathrm{H}), 2.38$ (broad s, complexed $\left.\mathrm{H}_{2} \mathrm{O}, 2 \mathrm{H}\right), 3.33-3.55(\mathrm{~m}, 12 \mathrm{H}), 3.71-3.73(\mathrm{~m}$, $2 \mathrm{H}), 4.30-4.33(\mathrm{~m}, 2 \mathrm{H}), 4.50$ (broad $\mathrm{s}, \mathrm{NH}, 1 \mathrm{H})$, the diastereotopic benzyl-type methylene protons next to pyridine carbon gave an $\mathrm{AB}$ quartet $\delta_{\mathrm{A}}: 4.55$ and $\delta_{\mathrm{B}}: 4.61(J=13 \mathrm{~Hz}, 4 \mathrm{H}), 6.41$ $(\mathrm{s}, 2 \mathrm{H}), 7.19-7.29(\mathrm{~m}, 5 \mathrm{H}) ;{ }^{13} \mathrm{C} \mathrm{NMR}\left(\mathrm{CDCl}_{3}\right) \delta 17.38,47.26,70.81,70.92,72.19,73.63,75.95$, 104.73, 127.58, 127.75, 128.99, 138.35, 154.52, 158.96. MS: $431(\mathrm{M}+1)^{+}$; Anal. Calcd. for $\mathrm{C}_{24} \mathrm{H}_{34} \mathrm{~N}_{2} \mathrm{O}_{5} \cdot \mathrm{H}_{2} \mathrm{O}: \mathrm{C}, 64.26 ; \mathrm{H}, 8.09 ; \mathrm{N}, 6.25$. Found C, 64.06; H, 8.12; N, 6.16.

\section{(4S,14S)-4,14-Dimethyl-3,6,9,12,15-pentaoxa-21-azabicyclo[15.3.1] heneicosa-1(21),17,19-}

trien-21-oxide $[(S, S)$-19]. To a stirred solution of dimethyl-substituted parent pyridino-crown ether $(S, S)-1(312 \mathrm{mg}, 0.96 \mathrm{mmol})$ in pure and dry $\mathrm{CH}_{2} \mathrm{Cl}_{2}(6 \mathrm{~mL})$ at $\mathrm{rt}$ under $\mathrm{Ar}$ was added MCPBA (500 mg, $2.9 \mathrm{mmol}$ ), and the resulting mixture was stirred at $\mathrm{rt}$ under Ar for 1 day. After the reaction was completed the solvent was removed and the residue was subjected to column chromatography on $\mathrm{Al}_{2} \mathrm{O}_{3}$ using toluene: $\mathrm{EtOH}$ 120:1 as an eluent to give $(S, S)-19$ (255 $\mathrm{mg}, 78 \%)$ as a thick oil. $[\alpha]^{25}=+25.6\left(c 1.0, \mathrm{CHCl}_{3}\right)$; IR (neat) $v_{\max } 2864,1456,1408,1300$, $1248,1116,848,784 \mathrm{~cm}^{-1} ;{ }^{1} \mathrm{H}$ NMR $\left(\mathrm{CDCl}_{3}\right) \delta 1.20(\mathrm{~d}, J=6 \mathrm{~Hz}, 6 \mathrm{H}), 3.37-3.51(\mathrm{~m}, 12 \mathrm{H}), 3.91-$ $4.01(\mathrm{~m}, 2 \mathrm{H})$, the diastereotopic benzyl-type protons gave an $\mathrm{AB}$ quartet $\delta_{\mathrm{A}}: 4.84$ and $\delta_{\mathrm{B}}: 5.11(\mathrm{~J}$ $=16 \mathrm{~Hz}, 4 \mathrm{H}) 7.26(\mathrm{t}, J=8 \mathrm{~Hz}, 1 \mathrm{H}), 7.42(\mathrm{~d}, J=8 \mathrm{~Hz}, 2 \mathrm{H}) ;{ }^{13} \mathrm{C} \mathrm{NMR}\left(\mathrm{CDCl}_{3}\right) \delta$ 17.36, 65.36, 70.92, 71.30, 74.53, 76.23, 122.70, 124.43, 149.87; MS: $342(\mathrm{M}+1)^{+}$; Anal. Calcd. for $\mathrm{C}_{17} \mathrm{H}_{27} \mathrm{NO}_{6}$ : C, 59.81; H, 7.97; N, 4.10. Found C, 59.67; H, 7.99; N, 4.02.

(4S,14S)-21-Methoxy-4,14-dimethyl-3,6,9,12,15-pentaoxa-21-azoniabicyclo[15.3.1]

heneicosa-1(21),17,19-trien-methyl-sulfate $[(S, S)$-20]. Pyridino-crown ether $N$-oxide $(S, S)$-19 (800 mg, $2.34 \mathrm{mmol}$ ) and freshly distilled dimethyl sulfate (354 $\mathrm{mg}, 2.81 \mathrm{mmol})$ were mixed at $\mathrm{rt}$ under $\mathrm{Ar}$ and this mixture was stirred at $\mathrm{rt}$ for $1 \mathrm{~h}$ and at $100^{\circ} \mathrm{C}$ for 1 day. $\mathrm{CHCl}_{3}(15 \mathrm{~mL})$ and $\mathrm{H}_{2} \mathrm{O}(15 \mathrm{~mL})$ were added to the cold reaction mixture, the phases were shaken well and separated. The aqueous phase was shaken with $\mathrm{CHCl}_{3}(5 \mathrm{~mL})$. The water was removed from the aqueous phase at $25^{\circ} \mathrm{C}$ (in the end at $0.05 \mathrm{mmHg}$ ) and the residue was dried over $\mathrm{P}_{2} \mathrm{O}_{5}$ under reduced pressure in a desiccator for a day. This crude $(S, S)-\mathbf{2 0}(820 \mathrm{mg}, 75 \%$, a thick oil) proved to be fairly pure and it was used for the next step without further purification. $[\alpha]^{25}=+36.3(\mathrm{c}$ $0.4, \mathrm{MeOH}$ ); IR (neat) $v_{\max } 3416,3144,2904,1616,1456,1352,1256,1152,1124,1036,1008$, 
944, $756 \mathrm{~cm}^{-1}$; ${ }^{1} \mathrm{H}$ NMR $\left(\mathrm{D}_{2} \mathrm{O}\right) \delta 1.18(\mathrm{~d}, J=6 \mathrm{~Hz}, 6 \mathrm{H}), 3.38-3.47$ (m, $\left.12 \mathrm{H}\right), 3.66(\mathrm{~s}, 3 \mathrm{H}), 3.89-$ $3.97(\mathrm{~m}, 2 \mathrm{H}), 4.41(\mathrm{~s}, 3 \mathrm{H})$, the diastereotopic benzyl-type protons gave an AB quartet $\delta_{\mathrm{A}}: 5.00$ and $\delta_{\mathrm{B}}: 5.24(J=15.0 \mathrm{~Hz}, 4 \mathrm{H}), 8.15(\mathrm{~d}, J=8 \mathrm{~Hz}, 2 \mathrm{H}), 8.49(\mathrm{t}, J=8 \mathrm{~Hz}, 1 \mathrm{H}) ;{ }^{13} \mathrm{C}$ NMR $\left(\mathrm{D}_{2} \mathrm{O}\right) \delta$ $15.44,55.46,64.32,70.01,70.52,74.98,75.82,129.07,145.46,152.92$.

(4S,14S)-4,14-Dimethyl-3,6,9,12,15-pentaoxa-21-azabicyclo[15.3.1]heneicosa-1(21),17,19trien-19-carbonitrile $[(\boldsymbol{S}, \boldsymbol{S})-\mathbf{1 8}]$. To a stirred solution of $N$-methoxypyridinium-crown ether methylsulfate $(S, S)-20(748 \mathrm{mg}, 1.6 \mathrm{mmol})$ in $\mathrm{MeOH}: \mathrm{H}_{2} \mathrm{O} 1: 5(\mathrm{v} / \mathrm{v})$ solvent mixture $(30 \mathrm{~mL})$ was added $\mathrm{NaCN}$ (784 mg, $16 \mathrm{mmol}$ ) at rt under Ar and it was stirred at rt under Ar for 2 days. After the reaction was completed the mixture was condensed to about a quarter of its original volume at $30^{\circ} \mathrm{C}, \mathrm{CH}_{2} \mathrm{Cl}_{2}(20 \mathrm{~mL})$ and water $(10 \mathrm{~mL})$ was added, shaken well and the phases were separated. The aqueous phase was shaken with $\mathrm{CH}_{2} \mathrm{Cl}_{2}(3 \mathrm{X} 5 \mathrm{~mL})$. The combined organic phase was dried over $\mathrm{MgSO}_{4}$, filtered and the solvent evaporated. The crude product was purified by column chromatography on $\mathrm{Al}_{2} \mathrm{O}_{3}$ using toluene:EtOH 140:1 as an eluent to give $(S, S)-18$ (73 mg, 13\%) as an oil. $[\alpha]^{25}=+18.9\left(c 0.79, \mathrm{CHCl}_{3}\right)$; IR (KBr) $v_{\max } 3128,3056,3024,2920,2232$ (CN), 1596, 1456, 1432, 1416, 1376, 1352, 1344, 1336, 1296, 1120, 1052, 1032, 904, 856, 600 $\mathrm{cm}^{-1} ;{ }^{1} \mathrm{H}$ NMR $\left(\mathrm{CDCl}_{3}\right) \delta 1.19(\mathrm{~d}, J=6 \mathrm{~Hz}, 6 \mathrm{H}), 3.43-3.61(\mathrm{~m}, 12 \mathrm{H}), 3.81-3.84(\mathrm{~m}, 2 \mathrm{H})$, the diastereotopic benzyl-type methylene protons gave an $\mathrm{AB}$ quartet $\delta_{\mathrm{A}}: 4.87$ and $\delta_{\mathrm{B}}: 4.91(\mathrm{~J}=14$ $\mathrm{Hz}, 4 \mathrm{H}), 7.48(\mathrm{~s}, 2 \mathrm{H}) ;{ }^{13} \mathrm{C} \mathrm{NMR}\left(\mathrm{CDCl}_{3}\right) \delta 17.16,70.87,71.11,71.36,74.49,76.53,121.05$, 121.59, 156.52, 160.80; MS: $351(\mathrm{M}+1)^{+}$. Anal. Calcd. for $\mathrm{C}_{18} \mathrm{H}_{26} \mathrm{~N}_{2} \mathrm{O}_{5}: \mathrm{C}, 61.70 ; \mathrm{H}, 7.48 ; \mathrm{N}$, 7.99. Found $\mathrm{C}, 61.46 ; \mathrm{H}, 7.52 ; \mathrm{N}, 7.81$.

\section{Acknowledgements}

This work was supported by the Hungarian Scientific Research Fund (OTKA K62654) and by the Ministry of Education of Hungary (Postdoctoral Fellowship PAL 11/2003).

\section{References}

1. Davies, A. P. Chiral Guest Recognition. In Encyclopedia of Supramolecular Chemistry; Atwood, J. L.;Steed, J. W., Eds.; Marcel Dekker: New York, 2004; pp 236-244.

2. Kyba, E. P.; Koga, K.; Sousa, L. R.; Siegel, M. G.; Cram, D. J. J. Am. Chem. Soc. 1973, 95, 2692.

3. Kyba, E. P.; Timko, J. M.; Kaplan, L. J.; de Jong, F.; Gokel, G. W.; Cram, D. J. J. Am. Chem. Soc. 1978, 100, 4555.

4. Kubo, Y.; Maeda S.; Tokita, S.; Kubo, M. Nature 1996, 382, 522.

5. Zhang, X. X.; Bradshaw, J. S.; Izatt, R. M. Chem. Rev. 1997, 97, 3313.

6. Nakatsuji, Y.; Nakahara, Y.; Muramatsu, A.; Kida, T.; Akashi, M. Tetrahedron Lett. 2005, 46, 4331. 
7. Lee, C. S.; Teng, P. F.; Wong, W. L.; Kwong, H. L.; Chan A. S. C. Tetrahedron 2005, 61, 7924.

8. Jones, B. A.; Bradshaw, J. S.; Brown, P. R.; Christensen, J. J.; Izatt, R. M. J. Org. Chem. 1983, 48, 2635.

9. Bradshaw, J. S.; Huszthy, P.; McDaniel, C. W.; Zhu, C. Y.; Dalley, N. K.; Izatt, R. M.; Lifson S. J. Org. Chem. 1990, 55, 3219.

10. Huszthy, P.; Bradshaw, J. S.; Zhu, C. Y.; Izatt, R. M.; Lifson, S. J. Org. Chem. 1991, 56, 3330.

11. Huszthy, P.; Oue, M.; Bradshaw, J. S.; Zhu, C. Y.; Wang, T. M.; Dalley, N. K.; Curtis, J. C.; Izatt, R. M. J. Org. Chem. 1992, 57, 5383.

12. Wang, T. M.; Bradshaw, J. S.; Curtis, J. C.; Huszthy, P.; Izatt, R. M. J. Incl. Phenom. Mol. Recogn. Chem. 1993, 16, 113.

13. Chu, I. H.; Dearden, D. V.; Bradshaw, J. S.; Huszthy, P.; Izatt, R. M. J. Am. Chem. Soc. 1993, 115, 4318.

14. Izatt, R. M.; Wang, T. M.; Hathaway, J. K.; Zhang, X. X.; Curtis, J. C.; Bradshaw, J. S.; Zhu, C. Y.; Huszthy, P. J. Incl. Phenom. Mol. Recogn. Chem. 1994, 17, 157.

15. Hathaway, J. K.; Izatt, R. M.; Zhu C. Y.; Huszthy, P.; Bradshaw, J. S. Supramolecular Chem. 1995, $5,9$.

16. Nazarenko, A. Y.; Huszthy, P.; Bradshaw, J. S.; Lamb, J. D.; Izatt, R. M. J. Incl. Phenom. Mol. Recogn. Chem. 1995, 20, 13.

17. Pócsfalvi, G.; Lipták, M.; Huszthy, P.; Bardshaw, J. S.; Izatt, R. M.; Vékey, K. Anal. Chem. 1996, 68, 792.

18. Wang T. M.; Bradshaw, J. S.; Huszthy, P.; Izatt, R. M. Supramolecular Chem. 1996, 6, 251.

19. Habata, Y.; Bradshaw, J. S.; Young, J. J.; Castle, S. L.; Huszthy, P.; Pjo, T.; Lee, M. L.; Izatt, R. M. J. Org. Chem. 1996, 61, 8391.

20. Somogyi, L.; Huszthy, P.; Bradshaw, J. S.; Izatt, R. M.; Hollósi, M. Chirality 1997, 9, 545.

21. Dobó, A.; Lipták, M.; Huszthy, P.; Vékey, K. Rapid Commun. Mass. Spectrom. 1997, 11, 889.

22. Horváth, V.; Takács, T.; Horvai, G.; Huszthy, P.; Bradshaw, J. S.; Izatt, R. M. Anal. Lett. 1997, 30, 1591.

23. Somogyi, L.; Huszthy, P.; Köntös, Z.; Hollósi, M. Enantiomer 1998, 3, 439.

24. Samu, E.; Huszthy, P.; Horváth, G.; Szöllősy, A.; Neszmélyi, A. Tetrahedron: Asymmetry 1999, 10, 3615.

25. Farkas, V.; Szalay, L.; Vass, E.; Hollósi, M.; Horváth, Gy.; Huszthy, P. Chirality 2003, 15, S65.

26. Gerencsér, J.; Báthori, N.; Czugler, M.; Huszthy, P.; Nógrádi, M. Tetrahedron: Asymmetry 2003, 14, 2803.

27. Bradshaw, J. S.; Huszthy, P.; Wang, T. M.; Nazarenko, A. Y.; Izatt, R. M. Supramolecular Chem. 1993, 1, 267. 
28. Huszthy, P.; Bradshaw, J. S.; Bodurov, A. V.; Izatt, R. M. ACH-Models in Chemistry 1994, $131,445$.

29. Köntös, Z.; Huszthy, P.; Bradshaw, J. S.; Izatt, R. M. Tetrahedron: Asymmetry 1999, 10, 2087.

30. Köntös, Z.; Huszthy, P.; Bradshaw, J. S.; Izatt, R. M. Enantiomer 2000, 5, 561.

31. Horváth, G.; Huszthy, P.; Szarvas, S.; Szokán, G.; Redd, J. T.; Bradshaw, J. S.; Izatt, R. M. Ind. Eng. Chem. Res. 2000, 39, 3576.

32. Farkas, V.; Tóth, T.; Orosz, G.; Huszthy, P.; Hollósi, M. Tetrahedron: Asymmetry 2006, 17, 1883.

33. Horváth, G.; Huszthy, P. Tetrahedron: Asymmetry 1999, 10, 4573.

34. Cooper, K. D.; Walborsky, H. M. J. Org. Chem. 1981, 46, 2110.

35. Jones, B. A.; Bradshaw, J. S.; Izatt, R. M. J. Heterocycl. Chem. 1982, 19, 551.

36. Lüning, U.; Baumstark, R.; Müller, M. Liebigs Ann. Chem. 1991, 987.

37. Feely, W. E.; Beavers, E. M. J. Am. Chem. Soc. 1959, 81, 4004.

38. Riddick, J. A.; Burger, W. B. Organic Solvents. In Techniques of Organic Chemistry; Weissberger, A. Ed.; Wiley -Interscience: New York, 1970; Vol. II. 